\title{
Pengaruh Kuliah Daring Terhadap Pemahaman Mahasiswa Tingkat Pertama Pada Mata Kuliah Etika Keperawatan
}

\author{
${ }^{1}$ Edita Revine Siahaan*, \\ ${ }^{1}$ Akademi Keperawatan Bunda Delima Bandar Lampung \\ Email : editasiahaan@bundadelimalampung.ac.id
}

\begin{abstract}
Kata kunci :
Daring, Mahasiswa,

Keperawatan
\end{abstract}

Keywords : Online,

Student, Nursing

Info Artikel:

Tanggal dikirim :

29 Maret 2021

Tanggal direvisi :

1 April 2021

Tanggal diterima :

15 April 2021

DOI Artikel:

10.33862/citradelima. v5i1.214

Halaman: 18-22

\section{Abstrak}

Mata kuliah etika keperawatan adalah mata kuliah wajib yang harus di tempuh oleh mahasiswa keperawatan. Dampak perkuliahan daring oleh mahasiswa tingkat pertama adalah sulit beradaptasi dengan perkuliahan daring secara teori dan praktik, jaringan internet yang tidak stabil, serta konsentrasi mahasiswa pada saat kuliah daring. Tujuan penelitian ini adalah mengidentifikasi pengaruh kuliah daring terhadap pemahaman mahasiswa tingkat pertama pada mata kuliah etika keperawatan. Desain penelitian ini menggunakan metode quasy experimental design tanpa kelompok control dengan metode pendekatan one group pretest posttest design. Populasi dalam penelitian ini adalah semua mahasiswa tingkat pertama. Sampel sebanyak 50 mahasiswa dan intervensi yang dilakukan peneliti dengan memberikan 20 soal Pre test dan 20 soal Post Test melalui aplikasi Ed Link. Analisis statistic pada penelitian ini menggunakan program computer. Analisis bivariat menggunakan Uji Mc Nemar. Hasil penelitian ini menunjukkan bahwa ada perbedaan yang signifikan pada pemahaman mahasiswa sebelum dan sesudah diberikan materi perkuliahan dengan nilai $P$ Value $0,000(<0,05)$. Kesimpulan dari penelitian ini adalah bahwa ada pengaruh yang signifikan kuliah daring terhadap pemahaman mahasiswa tingkat pertama pada mata kuliah etika keperawatan.

\section{The Influence of Online Lectures on First Level Student Understanding In Nursing Ethics Course}

Abstract
Nursing ethics course is a compulsory subject that nursing students must take. The
impact of online lectures by first year students is that it is difficult to adapt to online
lectures in theory and practice, unstable internet networks, and student concentration
during online lectures. The purpose of this study was to identify the effect of online
lectures on the understanding of first-year students in nursing ethics courses. The
research design used the quasy experimental design method without a control group with
the one group pretest posttest design approach. The population in this study were all
first-year students. A sample of 50 students and the intervention conducted by
researchers by giving 20 pre-test questions and 20 post-test questions through the Ed
Link application. Statistical analysis in this study using a computer program. Bivariate
analysis using the Mc Nemar test. The results of this study indicate that there is a
significant difference in the understanding of students before and after being given
lecture material with a P value of 0.000 (<0.05). The conclusion of this study is that
there is a significant effect of online lectures on the understanding of first-year students
in nursing ethics courses




\section{PENDAHULUAN}

Di Negara Indonesia sejak bulan maret tanggal 23 tahun 2020 dilanda masalah pandemi covid 19 yang tidak hanya mengancam dunia kesehatan, tetapi dalam bidang ekonomi serta bidang pendidikan khususnya menjadi terhenti dalam proses pembelajaran tatap muka. Pemerintah memutuskan untuk proses pembelajaran dilakukan secara online tanpa terkecuali di semua Perguruan Tinggi di Indonesia baik swasta maupun negeri. Perguruan tinggi negeri dan swasta yang ada diseluruh Indonesia mengikuti surat edaran dari Kemenristek tahun 2020 tentang pencegahan penyebaran corona virus dikalangan mahasiswa dan dosen. Dalam mencegah penyebaran virus covid 19 di lingkungan kampus Indonesia menerapkan kebijakan perkuliahan dengan online dengan berbasis daring (Kemendikbud, 2020).

Hal ini pernah diprediksikan oleh Thomas L. Friedman bahwa perkuliahan mahasiswa dapat tersambung dengan komputer dengan duduk dirumah saja sehingga pendidikan dapat dirasakan oleh semua orang dimana saja, dan kapan saja serta oleh semua kalangan dengan sebidangnya atau interbidang dibelahan dunia (Kusnayat, 2020).

Permasalahan Pembelajaran online adalah hal yang baru di Akper Bunda Delima, baik bagi mahasiswa maupun oleh dosen. Surat edaran nomor 36962/MPK.A/HK/2020 menjelaskan bahwa semua proses kegiatan perkuliahan menggunakan metode online sebagai upaya pencegahan dalam penularan covid 19 (Alfonsius, 2020). Media pembelajaran online di Akper Bunda Delima sangat dirasakan oleh mahasiswa, khususnya mahasiswa tingkat pertama pada mata kuliah etika keperawatan. Mata kuliah etika keperawatan terdapat 1 sks teori dengan 7 kali pertemuan dan 1 sks (system kredit semester) praktek dengan 14 kali pertemuan. Mata kuliah etika keperawatan dengan adanya pandemi covid 19 mahasiswa tingkat pertama tidak dapat dilakukan dengan perkuliahan tatap muka secara teori dan praktik, kuliah tidak bisa dilakukan di kelas tetapi dilakukan secara onlne dengan materi power point yang sudah diberikan oleh dosen kepada mahasiswa lewat aplikasi ed link.

Pada aplikasi ed link mahasiswa menggunakan jaringan internet yang mengakibatkan biaya menjadi lebih besar dan menggunakan perkuliahan lewat daring, tidak dapat berinteraksi secara langsung kepada dosen perkuliahan praktik sehingga mahasiswa sulit memahami materi yang sudah diberikan serta mahasiswa tingkat pertama adalah mahasiswa ditahun pertama menempuh perkuliahan di perguruan tinggi sehingga sulit beradaptasi kurikulum dengan system kredit semester (Suni Astini, 2020).

Hal ini didukung oleh penelitian Mulyapradana tahun 2020 bahwa penggunaan dengan sistem daring mempunyai pengaruh dalam proses perkuliahan online dengan mengalami masalah seperti tingkat perhatian mahasiswa yang sangat kurang dan kendala jaringan internet serta keterbatasan kuota internet mahasiswa serta penelitian di PTS Aceh (Perguruan tinggi swasta) dampak pembelajaran daring oleh mahasiswa sulitnya interaksi dosen dan mahasiswa dalam proses pembelajaran perkuliahan secara daring (Rahma, 2021).

Mata kuliah etika keperawatan adalah mata kuliah wajib yang harus di tempuh oleh mahasiswa akademi keperawatan. Dampak dari perkuliahan online oleh mahasiswa tingkat pertama adalah sulitnya beradaptasi dengan system satuan kredit semester, kurangnya perhatian mahasiswa dalam pembelajaran mata kuliah melalui ed link, jaringan internet yang lambat dalam perkuliahan online, keterbatasan kuota internet mahasiswa, sulitnya konsentrasi mahasiswa dalam perkuliahan daring, proses kuliah online saat pemaparan materi oleh dosen dengan mahasiswa sulit menerima pengetahuan karena system kuliah online dengan teori dan praktik. Mata kuliah yang menggunakan praktik sangat kurang efektif jika dilakukan dengan metode online karena sulitmya berinteraksi dosen dan mahasiswa ketika ada materi praktik yang sulit dipahami karena komunikasi satu arah, mahasiswa tingkat pertama cemas dalam menghadapi perkuliahan secara daring.

Berdasarkan data yang telah disebutkan diatas terkait kasus dan dampak bahaya penyebaran covid 19, juga diikuti dengan tingginya angka kasus konfirmasi covid 19 di Lampung dibulan desember 2020. Tujuan penelitian ini adalah untuk menganalisis pengaruh kuliah daring terhadap pemahaman mahasiswa pada mata kuliah etika keperawatan di Akper Bunda Delima. Manfaat penelitian ini bagi mahasiswa adalah untuk meningkatkan minat belajar dengan kuliah online serta memberikan support perhatian untuk motivasi dalam perkuliahan berbasis daring Manfaat bagi dosen diharapkan dapat meningkatkan kreativitas dosen sebagai pengajar dalam proses pembelajaran dalam perkuliahan metode online dalam system daring serta evaluasi untuk semester berikutnya khususnya mata kuliah yang berbasis teori dan praktik.

http://jurnalilmiah.stikescitradelima.ac.id/index.php/JI Vol. 5 No. 1 Juli 2021 


\section{METODE}

Penelitian ini adalah penelitian kuantitatif dengan desain penelitian menggunakan metode quasy experimental design tanpa kelompok control dengan metode pendekatan one group pretest posttest design. Populasi dalam penelitian ini adalah seluruh mahasiswa tingkat pertama mahasiswa Akper Bunda Delima Bandar lampung sebanyak 50 mahasiswa.

Sampel penelitian ini menggunakan total sampling yaitu adalah semua mahasiswa tingkat pertama akper Bunda Delima Bandar lampung yang berusia 18 tahun sampai dengan 19 tahun. Jumlah sampel dalam penelitian ini adalah sebanyak 50 mahasiswa. Mahasiswa ini tercatat secara administratif dalam mata kuliah etika keperawatan beserta NPM (Nomor Pokok Mahasiswa).

Responden bersedia mengikuti proses penelitian serta memberikan tanda tangan persetujuan (lembar inform consent) untuk menjadikan subjek dalam penelitian ini. Responden mengikuti program penelitian ini yang diberikan secara keseluruhan dari awal penelitian sampai akhir penelitian. Tempat penelitian ini dilakukan di Akper Bunda Delima.

Waktu pengumpulan data dilaksanakan selama 1 hari pada tanggal 29 Januari 2021 sebelumnya peneliti meminta ijin kepada Direktur Akper Bunda Delima untuk melakukan penelitian. Pemberian inform consent kepada mahasiswa dilakukan dengan menggunakan aplikasi ed link, dua hari sebelum penelitian dilakukan.

Pengambilan data dilakukan dengan melakukan penilaian dalam pemahaman mata kuliah etika dengan materi konsep etika keperawatan. Sebelum pemberian konsep materi mahasiswa diberikan 20 pertanyaan yang harus dijawab dengan waktu 10 menit.

Setelah itu pemberian materi dilakukan selama 100 menit, dengan menggunakan aplikasi ed link. Setalah materi selesai mahasiswa diberikan soal yang sama tentang konsep materi yang sudah diajarkan. Pada penelitian ini dosen melakukan observasi melalui aplikasi ed link video conference pada semua mahasiswa dalam perkuliahan. Dalam perkuliahan ini peneliti mengobservasi melalui video conference proses internet pembelajaran daring pada mahasiswa baik, serta kemampuan mahasiswa menggunakan aplikasi ed link. Uji statistik pada penelitian ini yang digunakan adalah dengan menggunakan uji $M c$ Nemar. Uji Mc Nemar adalah uji statistic metode non parametric dengan analisis Mc Nemar Test untuk dua sampel saling berhubungan.
Etika penelitian dilakukan oleh peneliti dengan menggunakan pemberian inform consent sebelum dilakukan penelitian, Manfaat (Beneficience) peneliti melakukan prinsip beneficience yaitu satu prinsip yang menumbuhkan hubungan kerja sama yang baik dengan mahasiswa. Peneliti memberi manfaat langsung dalam penelitian ini kepada mahasiswa. Justice adalah peneliti melakukan prinsip justice dengan dua cara yaitu responden diperlakukan adil dalam penelitian dan mendapatkan respect for person. Penelitian ini tidak membedakan status atau golongan dalam menentukan sampel. Responden dalam penelitian ini diambil semua dengan sampel sesuai dengan tujuan peneliti.

Sedangkan etika penelitian hak mahasiswa untuk mendapatkan privacy diberikan kepada dengan menjamin kerahasiaan bahwa data dan segala informasi yang bersifat pribadi serta tidak menyebarluaskan dan menjaga kerahasiaanya.

\section{HASIL DAN PEMBAHASAN}

Hasil

\section{A. Analisis Univariat}

Tabel 1. Distribusi Frekuensi Responden

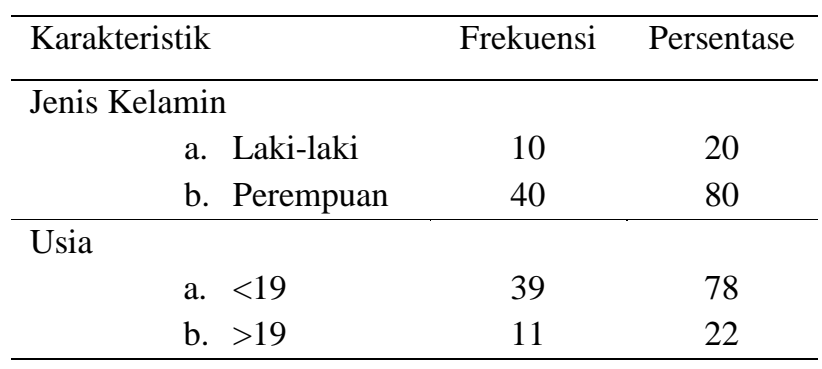

Proses Internet

Pembelajaran Daring

$\begin{array}{llr}\text { a. Baik } & 47 & 94 \\ \text { b. Kurang } & 3 & 6\end{array}$

Pendidikan Orang Tua

$\begin{array}{lcc}\text { a. SMP } & 0 & 0 \\ \text { b. SMA } & 36 & 72 \\ \text { c. Universitas } & 14 & 28\end{array}$

\begin{tabular}{|c|c|c|}
\hline \\
\hline \multicolumn{3}{|l|}{ Menggunakan Aplikasi } \\
\hline a. Baik & 49 & 98 \\
\hline b. Kurang & 1 & 2 \\
\hline
\end{tabular}

http://jurnalilmiah.stikescitradelima.ac.id/index.php/JI Vol. 5 No. 1 Juli 2021 
Karakteristik responden berdasarkan tabel 1 diketahui bahwa sebagian besar bahwa sebagian besar responden jenis kelamin perempuan sebanyak 40 mahasiswa $(80 \%)$, usia responden $<19$ tahun sebanyak 39 mahasiswa (78\%), dan proses internet pembelajaran daring 47 responden mendominasi baik (94\%), Pendidikan terakhir orang tua lulusan SMA sebanyak 36 orang tua $(72 \%)$, serta kemampuan mahasiswa menggunakan aplikasi sebanyak 49 responden (98\%).

\section{B. Analisis Bivariat}

Tabel 2. Distribusi frekuensi sebelum dan sesudah Pengaruh kuliah daring terhadap pemahaman mahasiswa tingkat pertama pada mata kuliah etika keperawatan

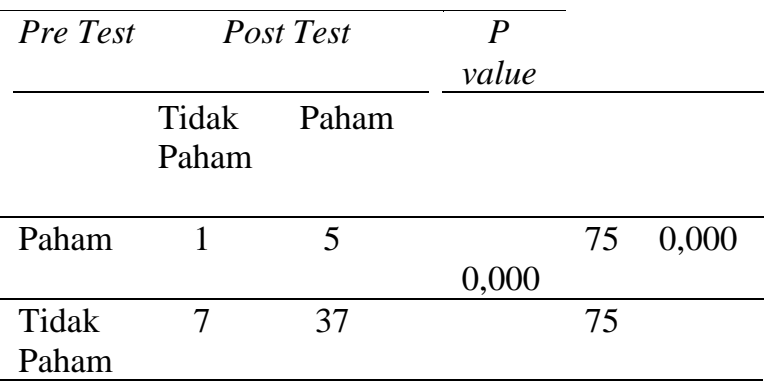

Berdasarkan tabel 2 hasil uji Mc Nemar dengan nilai $P$ Value 0,000 . Pada saat dilakukan pre test responden yang tidak paham mata kuliah etika keperawatan dan diberikan post test menjadi paham sebanyak 37 responden. Sedangkan responden yang tidak ada perubahan pemahaman mata kuliah pre test dan post test sebanyak 7 responden tidak paham materi kuliah etika kperawatan. Dapat disimpulkan bahwa ada pengaruh kuliah daring terhadap pemahaman mahasiswa tingkat pertama pada mata kuliah etika keperawatan.

\section{Pembahasan}

\section{Perbedaan tingkat pengetahuan sebelum dan sesudah diberikan materi}

Hasil penelitian ini menunjukkan tingkat pengetahuan quis responden sebelum dan sesudah diberikan materi konsep etika keperawatan lewat aplikasi ed link menunjukkan ada peningkatan pemahaman yang signifikan yaitu 37 responden (74\%). Usia remaja peralihan ke dewasa adalah usia yang sangat cepat menerima informasi atau pengetahuan. Pengetahuan adalah proses hasil dari tahu yang terjadi ketika individu melakukan aktivitas dengan pengindraan terhadap suatu objek. Pengetahuan membentuk suatu perilaku yang menetap dan akan dilakukan sebagai tindakan oleh individu tersebut (Notoadmodjo, 2014 ; Pratama, 2020).

Faktor yang mempengaruhi pengetahuan individu adalah jenis kelamin, usia, pendidikan, media informasi, lingkungan, sosial budaya dan ekonomi, sikap. Seseorang yang berpendidikan rendah tidak berarti memiliki pengetahuan yang rendah. Tetapi pendidikan yang tinggi akan mudah menyerap pengetahuan. Peningkatan pengetahuan individu terhadap objek bermakna 2 aspek yaitu aspek positif dan aspek negative. Aspek ini yang menentukan sikap seorang individu serta terpaparnya informasi media informasi Media informasi mempengaruhi seseorang untuk lebih mudah menyerap pengetahuan baru (Budiman dan Riyanto, 2013). Hasil penelitian ini sejalan dengan penelitian Merlin (2020) menunjukkan ada pengaruh pembelajaran e-daring terhadap mata kuliah keperawatan medical bedah pada mahasiswa semester empat di Kupang.

Pada penelitian ini kemampuan menggunakan aplikasi 49 responden (98\%) dapat menggunakan dengan baik. Sehingga materi yang diberikan oleh dosen adalah mata kuliah etika keperawatan dapat mengalami perubahan nilai quis yang signifikan. Faktor yang mempengaruhi pengetahuan yaitu minat serta sikap seseorang terhadap pengetahuan yang baru. Jika tidak ada minat dari responden, pengetahuan tidak terjadi perubahan perilaku.

Perubahan perilaku dapat bermakna positif atau negatif. Dalam penelitian ini terdapat 7 responden yang tidak mengalami perubahan pengetahuan, nilai quis tidak mengalami peningkatan signifikan. Hambatan dari penerimaan pengetahuan responden dalam perkuliahan online adalah konsentrasi responden dalam mendengar materi, masalah jaringan internet pada saat perkuliahan sehingga materi tidak terdengar jelas oleh mahasiswa, kecemasan mahasiswa perkuliahan daring di tingkat pertama, serta minat. Peningkatan pengetahuan tidak selalu bermakna positif.

Pada penelitian ini terdapat 5 responden $(10 \%)$ yang mendapatkan nilai quis dengan nilai baik sebelum diberikan materi perkuliahan, responden dapat menjawab nilai quis dengan baik. Perilaku dibentuk melalui suatu tindakan dalam interaksi manusia dengan lingkungannya. Perilaku yang terbentuk pada seseorang bila didasari oleh pengetahuan akan lebih langgeng karena dengan didasari pengetahuan yang baik seseorang akan dapat melakukan tindakan dengan benar dan dapat dipahami mengapa tindakan itu harus dilakukan(Notoadmodjo,2012).

http://jurnalilmiah.stikescitradelima.ac.id/index.php/JI Vol. 5 No. 1 Juli 2021 
Penelitian ini diperkuat oleh Ramadhan (2021) ada pengaruh pembelajaran berbasis online terhadap efektivitas pembelajaran mahasiswa di Malang. Metode pembelajaran mahasiswa keperawatan dengan menggunakan elektronik merupakan metode pembelajaran yang membutuhkan variasi dan kesiapan dari banyak pihak terutama dosen serta mahasiswa (Sianturi, 2018).

\section{KESIMPULAN DAN SARAN}

\section{Kesimpulan}

Terdapat perbedaan yang signifikan pemahaman mahasiswa sebelum dan sesudah diberikan materi etika keperawatan antara pretest dan posttest dengan nilai $P$ value adalah 0,000 yang menunjukkan bahwa nilai $P$ value tersebut lebih kecil dari $0,05(<0,05)$.

\section{Saran}

Peneliti selanjutnya disarankan untuk menggunakan populasi yang jumlahnya lebih dari 100 responden sehingga dapat melihat permasalahan lebih relevan.

Untuk peneliti selanjutnya diharapkan mengambil masalah penelitian perkuliahan online berbasis aplikasi praktik sehingga dapat melihat perbedaan masalah dengan perkuliahan daring secara teori.

Untuk peneliti selanjutnya diharapkan dapat mengambil masalah penelitian lainnya dengan melihat pengaruh proses pembelajaran penggunaan aplikasi online jenis lainnya.

\section{DAFTAR PUSTAKA}

Alfonsius. (2020). Penyelanggaraan pembelajaran perguruan tinggi swasta di masa pandemic covid 19. Universitas Pelita Harapan, (5), 1-10

Budiman dan Riyanto (2013). Kapita selekta kuesioner: pengetahuan dan sikap penelitian kesehatan. Jakarta: Salemba medika.

Kusnayat. (2020). Pengaruh tekhnologi pembelajaran kuliah online di era covid 19 dan dampaknya terhadap mental mahasiswa. Jurnal Edukasi dan Tekhnologi Pembelajaran, (1), 153-165

Merlin. (2020). Pengaruh pembelajaran dengan metode e-learning terhadap pemahaman materi kuliah keperawatan medical bedah II pada mahasiswa keperawatan semester IV Stikes Maranatha Kupang. Jurnal Penelitian Kesehatan Suara Forikes, (11), 331-333.

Mulyapradana. (2020) Pengaruh penggunaan media daring dan motivasi belajar terhadap kepuasan mahasiswa pada saat pandemic covid 19, Jurnal ITS NU pekalongan, 1-9.
Notoadmodjo. (2012). Metodologi Penelitian Kesehatan. Jakarta : PT.Rineka cipta.

Rahma. (2021). Dampak pembelajaran daring terhadap motivasi belajar mahasiswa selama pandemic covid 19. Universitas Islam Malang, 1(12), 113118.

Ramdhan. (2021). Pengaruh pembelajaran berbasis online terhadap efektivitas pembelajaran mahasiswa akuntansi unisma di era wabah covid 19. Universitas Islam Malang, 4(10), 58-67.

Sianturi. (2018). Peningkatan motivasi belajar melalui evaluasi e learning pada institusi keperawatan di Jakarta dan Depok. Jurnal Pendidikan Keperawata Indonesia, 122-130.

Suni Astini. (2020). Pemanfaatan tekhnologi informasi dalam pembelajaran. Jurnal Lampuhyang Lembaga Penjaminan Mutu, (11)13-25.

Surat Edaran Direktur jenderal Pendidikan Tinggi Republik Indonesia dan Kebudayaan tahun 2020 Tentang Pencegahan Penyebaran Covid 19 Kementrian Pendidikan dan Kebudayaan. 